\title{
Chronic In Utero Cyclooxygenase Inhibition Alters PGE2-Regulated Ductus Arteriosus Contractile Pathways and Prevents Postnatal Closure
}

\author{
JEFF REESE, NAHID WALEH, STANLEY D. POOLE, NAOKO BROWN, CHRISTINE ROMAN, AND RONALD I. CLYMAN \\ Department of Pediatrics, Cell and Developmental Biology [J.R., S.D.P., N.B.], Vanderbilt University, Nashville, Tennessee 37232; Life \\ Sciences Division [N.W.], SRI International, Menlo Park, California 94025; Department of Pediatrics [C.R., R.I.C.], University of \\ California, San Francisco, California 94143
}

\begin{abstract}
Although prostaglandin E2 (PGE2) vasodilates the ductus arteriosus, tocolysis with cyclooxygenase (COX) inhibitors delays postnatal ductus arteriosus closure. We used fetal mice and sheep to determine whether PGE2 has a role in the development of ductus contractility that is distinct from its function as a vasodilator. Prolonged exposure of fetal ductus to PGE2 in vitro increased the expression of $\mathrm{CaL}$ - and $\mathrm{K}^{+}$-channel genes $(\mathrm{CaL} \alpha 1 \mathrm{c}, \mathrm{CaL} \beta 2$, Kir6.1, and $\mathrm{Kv1.5}$, which regulate oxygen-induced constriction) without affecting the genes that regulate Rho-kinase-mediated calcium sensitization. Conversely, chronic exposure to $\mathrm{COX}$ inhibitors in utero decreased expression of $\mathrm{CaL}$ - and $\mathrm{K}^{+}$-channel genes, without affecting Rho-kinase-associated genes. Chronic COX inhibition in utero decreased the ductus' in vitro contractile response to stimuli that use CaL- and $\mathrm{K}^{+}$-channels (like $\mathrm{O}_{2}$ and $\mathrm{K}^{+}$), whereas the response to stimuli that act through Rho-kinase-mediated pathways (like U46619) was not significantly affected. Phosphodiesterase expression, which decreases the ductus' sensitivity to cAMP- or cGMPdependent vasodilators, was increased by PGE2 exposure and decreased by COX inhibition, respectively. These studies identify potential downstream effectors of a PGE2-mediated, developmental program, regulating oxygen-induced ductus closure. Alterations in these effectors may explain the increased risk of patent ductus arteriosus (PDA) after in utero COX inhibition. (Pediatr Res 66: 155-161, 2009)
\end{abstract}

$\mathrm{P}$ rostaglandins [especially prostaglandin E2 (PGE2)] vasodilate the fetal and neonatal ductus arteriosus. When nonselective inhibitors of cyclooxygenase (COX)-1 and -2, the rate-limiting enzymes for prostaglandin synthesis, are given to pregnant women to treat preterm labor, the ductus arteriosus constricts in utero (1). Surprisingly, some preterm infants, who are delivered after in utero exposure to indomethacin, have an increased, rather than decreased, incidence of patent ductus arteriosus (PDA) in the newborn period. The PDA in these infants fails to close with postnatal indomethacin treatment $(2,3)$. Delayed closure of the newborn ductus arteriosus increases an infant's risk for pulmonary hemorrhage, necrotizing enterocolitis and chronic lung disease (4).

Received January 5, 2009; accepted March 23, 2009.

Correspondence: Ronald Clyman, M.D., University of California San Francisco, 513 Parnassus Ave., Room 1408 HSW, UCSF Box 0544, San Francisco, CA 94143; e-mail: clymanr@peds.ucsf.edu

Supported by grants from US Public Health Service (NIH grants HL46691, HL77395) and by a gift from the Jamie and Bobby Gates Foundation.
Delayed closure of the newborn ductus also occurs in mice and sheep that have been exposed to nonselective COX inhibitors during the last $25 \%$ of gestation (5-7) and in mice lacking both COX genes (6-8). The basis for this paradoxical response is not entirely clear. Previous studies have suggested that in utero COX inhibition may contribute to delayed closure by increasing NO $(5,9)$ or decreasing hyaluronic acid production in the ductus (10).

Postnatal closure of the ductus arteriosus requires the presence of specific components of ductus contractility: smooth muscle calcium channels, potassium channels (11-15), Rhokinase-related calcium sensitizing pathways (11,16-18), mature myosin isoforms (19), and cytoskeletal proteins (20). Events or drugs that interfere with these pathways lead to delayed postnatal ductus closure (16,17,21-23). We speculated that prostaglandins may regulate the development of one or more of these contractile pathways and hypothesized that inhibition of COX activity in utero may alter the contractile apparatus' development, leading to a persistent PDA after birth.

In the following study, we examined the effects of prostaglandin exposure and inhibition on fetal mice and sheep ductus. We found that in addition to its known vasodilator effects, PGE2 plays an important role in the expression of specific pathways that are necessary for the ductus' oxygeninduced closure after delivery.

\section{MATERIALS AND METHODS}

All protocols were approved by the Vanderbilt University and the University of California San Francisco Institutional Animal Care and Use Committees.

Mouse studies. Wild-type female CD-1 mice (7- to 8-wk old; Charles River, Raleigh, NC) were bred to produce timed pregnancies (d 1, presence of vaginal plug; term, $19 \mathrm{~d}$ ).

Pregnant females received either no drugs (control) or a combination of a selective COX-1 inhibitor (SC560, $30 \mathrm{mg} / \mathrm{kg} /$ dose, $0.2 \mathrm{~mL}$ gavage) and a selective COX-2 inhibitor (SC236, $15 \mathrm{mg} / \mathrm{kg} /$ dose, $0.2 \mathrm{~mL}$ gavage; Cayman Chemical Co., Ann Arbor, MI). Both the drugs cross the placenta (24). Pregnant mice received the inhibitors either on a single occasion (d 19 of gestation) or chronically from d 15 to d 19 : SC560 (30 mg/kg/dose, twice daily) and SC236 (15 mg/kg/dose, every other day). Both fetuses and newborns were delivered by cesarian section, $4 \mathrm{~h}$ after the last drug dosage on $\mathrm{d}$

Abbreviations: COX, cyclooxygenase; PGE2, prostaglandin E2; PDA, patent ductus arteriosus 
19. Fetuses were euthanized at delivery. Newborn pups were placed in prewarmed cages in fraction of inspired oxygen $\left.\left(\mathrm{FiO}_{2}\right), 0.8-1.0\right]$ to accelerate ductus closure, and the tissues were harvested $4 \mathrm{~h}$ later. Tissues were prepared for either RNA analysis or histology as previously described $(6,25)$.

Determination of vessel caliber. Serial sections of fetal and newborn mouse thoraces were examined by an observer, who was blinded to the treatment group (R.I.C.). The inner diameters of the ductus arteriosus lumen (DA) and the transverse aortic arch lumen (AO) were determined at their narrowest points. DA diameter was expressed as a ratio of the ductus diameter to the diameter of the transverse aortic arch (DA/AO ratio) (6).

Mouse pressure myography studies. Fetal mouse ductus were isolated and mounted in 4-mL chambers as previously described (26). Distending pressure (in $\mathrm{mmHg}$ ) was generated by a column of deoxygenated Krebs buffer. Nonrecirculating, deoxygenated Krebs buffer $\left(36.5-37.5^{\circ} \mathrm{C}\right)$ perfused the chambers at $6 \mathrm{~mL} / \mathrm{min}$. The lumen diameter was measured, at the point of maximum constriction, using an inverted microscope and a video image capture system; during full vessel closure, measurement was obtained at the optically dense regions of the internal elastic lamina.

Vessels were initially pressurized to $20 \mathrm{~mm} \mathrm{Hg}$ (in $5 \mathrm{~mm} \mathrm{Hg}$ increments). The vessels were then exposed to $50 \mathrm{mM} \mathrm{K}{ }^{+}$- deoxygenated Krebs buffer (with $\mathrm{KCl}$ substituted for $\mathrm{NaCl}$ ) for 3-5 min to stimulate ductus contractility. After this, $N(G)$-nitro-l-arginine methyl ester (l-NAME) $\left(10^{-4} \mathrm{M}\right.$; Cayman Chemical Co.) and indomethacin $\left(5.6 \times 10^{-5} \mathrm{M}\right.$; Sigma-Aldrich Chemical Co., St. Louis, MO) were added to the perfusion solution, and the distending pressure was increased to $25 \mathrm{~mm} \mathrm{Hg}$ for the duration of the experiment. This eliminated any differences between the groups in ongoing NO and prostaglandin production in vitro $(9,27)$. After a 60 -min equilibration period with L-NAME and indomethacin at $25 \mathrm{~mm} \mathrm{Hg}$, the vessels were exposed to $50 \mathrm{mM} \mathrm{K}^{+}$- deoxygenated Krebs buffer for 3-5 min to stimulate ductus contractility.

Vessels from littermates were then exposed to one of the three study protocols: 1) increasing oxygen concentrations $\left(0,2,5,12\right.$, and $21 \% \mathrm{O}_{2} ; 5 \%$ $\mathrm{CO}_{2}$, balance $\left.\mathrm{N}_{2}\right)$, 2) increasing $\mathrm{K}^{+}$concentrations in deoxygenated $\left(95 \% \mathrm{~N}_{2}\right.$, $5 \% \mathrm{CO}_{2}$ ) Krebs buffer, or 3) increasing concentrations of U-46619, a thromboxane receptor agonist (Cayman Chemical Co.) in deoxygenated Krebs buffer. Each change in concentration was maintained until a stable new diameter was established (10-30 $\mathrm{min})$. At the completion of each study protocol, vessels were exposed to papaverine $\left(10^{-4} \mathrm{M}\right.$; Sigma-Aldrich Chemical Co.) to determine the vessel caliber at maximal relaxation.

Sheep studies: in vitro PGE2 incubation. The small size of the mouse ductus presented a great challenge in attempting to acquire sufficient tissue to perform the required number of biochemical analyses from individual ductus incubation studies. Therefore, we used the much larger fetal sheep ductus to examine the effects of PGE2 on isolated ductus arteriosus RNA expression. Immature sheep fetuses (mixed western breed: 103- \pm 2-d gestation; term, $145 \mathrm{~d})$ were delivered by cesarian section and anesthetized with i.v. ketamine $\mathrm{HCl}(30 \mathrm{mg} / \mathrm{kg}$ ) before rapid exsanguination. The ductus arteriosus was divided into $1-\mathrm{mm}$ thick rings ( 2 rings per animal), which were stretched to $5.0 \mathrm{~mm}$ in separate $20 \mathrm{~mL}$ organ chambers. Throughout the 23 -h experiment, the rings were perfused at $10 \mathrm{~mL} / \mathrm{h}$ with nonrecirculating modified Krebs buffer $\left(\mathrm{pH}, 7.4 ; 37.5^{\circ} \mathrm{C}\right)$ containing indomethacin $\left(5 \times 10^{-6} \mathrm{M}\right.$; to inhibit endogenous prostaglandin production; 28). Because of the tissue thickness, the chambers were continuously aerated with $30 \% \mathrm{O}_{2}, 5 \% \mathrm{CO}_{2}$, and balance $\mathrm{N}_{2}$. After a 3-h equilibration period, $10^{-8}$ M PGE2 [similar to fetal plasma concentrations at late gestation (29)] was added to the indomethacincontaining Krebs buffer perfusing one of the rings. The other ring continued to be perfused with the indomethacin-containing buffer without PGE2. Both rings were incubated for an additional $20 \mathrm{~h}$ before being snap frozen in liquid nitrogen for RNA analysis.

Preparation of total RNA, reverse transcription, and quantitative polymerase chain reaction. Total RNA was isolated from the mouse and sheep ductus, and the TaqMan Universal PCR master mix of PE Applied Biosystems (Foster City, CA) was used to quantify the expression of the genes as described elsewhere (25). Taqman probes were designed using the Primer Express program and labeled with fluorophores FAM (6-caboxy-fluorescein) and TAMRA (6 carboxy-tetramethyl-rhodamine) as reporter and quencher dyes, respectively. An ABI PRISM 7700 sequence detection system was used to determine the cycle threshold (CT). Malate dehydrogenase (MDH) was used as an internal control to normalize the data (11).

Statistics. Statistical analyses of unpaired and paired data were performed by the appropriate $t$ test and by analysis of variance. Scheffe's test was used for post hoc analysis. Values are expressed as mean \pm SD. Drug concentrations refer to their final molar concentration in the bath.

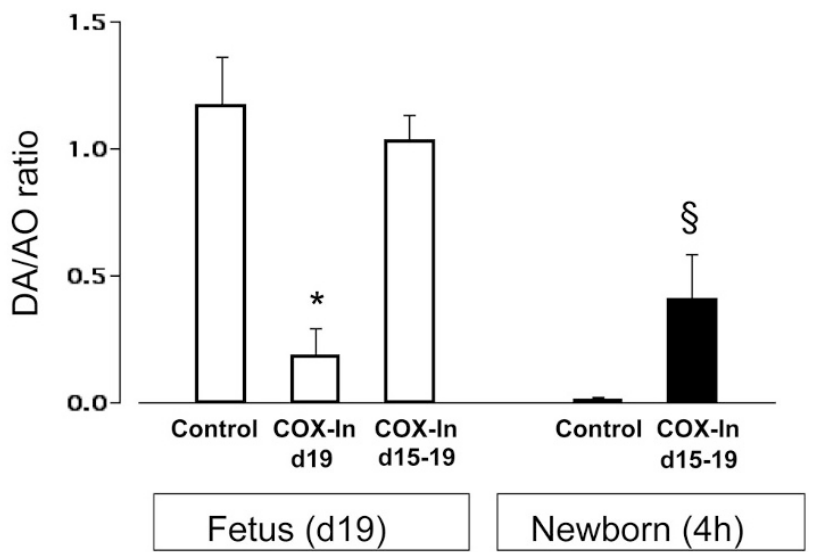

Figure 1. Response of the fetal and newborn ductus arteriosus to acute (COX-In d 19) and chronic (COX-In d 15-19) COX inhibition in vivo. DA, ductus and AO, transverse aorta lumen diameters. Acute COX inhibition constricted the fetal ductus at term gestation ( $n=17$ fetuses; 7 litters) compared with control fetuses ( $n=9 ; 6$ litters). Chronic COX inhibition $(n=$ 17; 6 litters) did not constrict the fetal ductus. Ductus closure in 4-h-old newborn pups (chronically exposed to COX inhibitors in utero $(n=26 ; 11$ litters) was significantly reduced (resulting in a PDA) compared with control newborns $(n=12 ; 4$ litters). $* p<0.05$ compared with fetal controls; $\$ p<$ 0.05 compared with newborn control.

\section{RESULTS}

A one-time exposure (on d 19 gestation) to the two selective COX inhibitors (SC560 plus SC236) produced marked constriction in vivo of the fetal mouse ductus arteriosus $4 \mathrm{~h}$ after administering the drugs (Fig. 1).

We wanted to examine the effects of chronic COX inhibition, which were independent of the initial acute constriction. Therefore, we started the chronic treatment (SC560 plus SC236) at a point in gestation (d 15) when the inhibitors had no acute contractile effect on the fetal mouse ductus (6) and continued the treatment regimen to d 19 of gestation. The ductus of fetuses that were exposed to the inhibitors (SC560 plus SC236) from d 15 to 19 of gestation did not constrict in utero, and they had the same degree of patency as control fetuses on d 16, 17, 18 (data not shown), and 19 (Fig. 1). Chronic exposure to the COX inhibitors in utero resulted in incomplete closure of the newborn ductus after birth (Fig. 1).

We next examined the effects of chronic COX inhibition on the ductus contractility using isolated pressurized ductus from control fetal mice and from mice exposed to the combined COX inhibitors (from d 15 to 19) in utero. Ductus smooth muscle contractility is determined by developmentally regulated pathways that control both the concentration of intracellular calcium and the sensitivity of the contractile proteins to changes in intracellular calcium. Intracellular calcium concentrations are determined by calcium influx through L-type calcium channels; similarly, Rho or Rho-kinase activity plays an important role in regulating calcium sensitization during the sustained phase of ductus contraction (11-17). Stimuli like oxygen and elevated $\mathrm{K}^{+}$affect ductus contractility primarily by increasing calcium entry through voltage-dependent $\mathrm{CaL}$ channels $(11,15,16,18,30,31)$. However, most agonists that alter vascular tone affect both aspects of ductus contractility. 

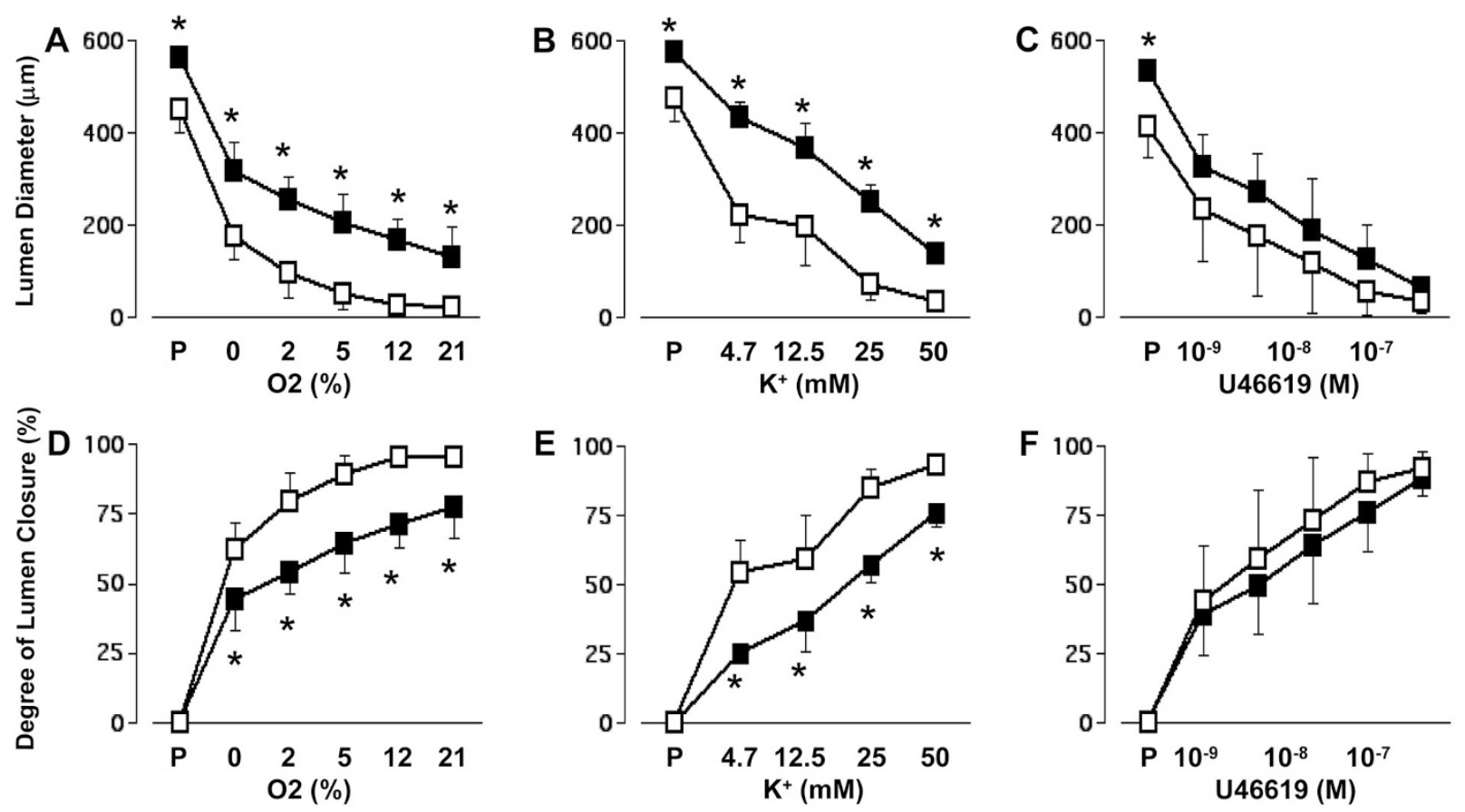

Figure 2. Contractile response of isolated ductus from19-d-old fetal mice treated with or without chronic COX inhibitors. Ductus were incubated in deoxygenated buffer containing L-NAME and indomethacin and exposed to increasing oxygen $(A, D), \mathrm{K}^{+}(B, E)$, or $\mathrm{U}-46619(C, F)$ concentrations. P, maximal relaxation with papaverine. Steady-state oxygen tensions were $42.5 \pm 2,57.3 \pm 2.1,75.1 \pm 1.8,118.8 \pm 1.7$, and $181.0 \pm 5.6 \mathrm{~mm} \mathrm{Hg}$ when the buffer was bubbled with $0,2,5,12$, and $21 \%$ oxygen, respectively. The $\mathrm{K}^{+}$and $\mathrm{U}-46619$ dose-response experiments were performed in $0 \%$ oxygen. Degree of lumen closure, 1-(measured diameter/diameter after papaverine relaxation). Open squares, controls; solid squares, chronic $\mathrm{COX}$ inhibition. Animal numbers: $\mathrm{O}_{2}(A, D)$ : control, 6; COX inhibition, 6; $\mathrm{K}^{+}(B, E)$ : control, 9; COX inhibition, 5; U-46619 $(C, F)$ : control, 7; COX inhibition, $6 . *^{*} p 0.05$ compared with control.

For example, in other vessels, U46619, a thromboxanemimetic, seems to affect both calcium entry and Rho-kinasemediated calcium sensitization $(32,33)$.

When incubated at the same pressures, under baseline conditions (buffer bubbled with $0 \% \mathrm{O}_{2}$ ), ductus obtained from term fetuses that were chronically exposed to COX inhibitors in utero had significantly larger lumina than control ductus (lumen diameter: COX-inhibitor exposed, $360 \pm 70 \mu \mathrm{m}, n=17$; control, $223 \pm 74 \mu \mathrm{m}, n=22, p<0.05$; Fig. 2). Similarly, when the ductus were maximally relaxed by papaverine, the lumina of the chronically COX-inhibited ductus were significantly larger than those of the control ductus (lumen diameter: COX-inhibitor exposed, $559 \pm 31 \mu \mathrm{m}$; control, $449 \pm 61$ $\mu \mathrm{m}, p<0.05)$. Ductus from both the groups constricted with increasing concentrations of $\mathrm{O}_{2}, \mathrm{~K}^{+}$, and $\mathrm{U} 46619$ (Fig. 2). However, $\mathrm{O}_{2}$ and $\mathrm{K}^{+}$produced a lesser degree of constriction in ductus that were chronically exposed to COX inhibitors in utero than they did in the control ductus (Fig. 2). On the other hand, the thromboxane-mimetic U46619 constricted both the groups of ductus to a similar degree (Fig. 2).

In the control ductus, peak concentrations of $\mathrm{O}_{2}(21 \%), \mathrm{K}^{+}$ $(50 \mathrm{mM})$, and $\mathrm{U} 46619\left(10^{-7} \mathrm{M}\right)$ produced the same maximal degree of constriction (\% closure: $95 \pm 2 \%, 93 \pm 4 \%$, and $92 \pm 6 \%$, respectively). In contrast, after chronic COX inhibition, U46619 $\left(10^{-7} \mathrm{M}\right)$ produced a significantly greater degree of ductus closure ( $\%$ closure, $88 \pm 5$ ) than either $21 \%$ $\mathrm{O}_{2}$ (\% closure, $\left.77 \pm 11 ; p<0.05\right)$ or $50 \mathrm{mM} \mathrm{K}^{+}$(\% closure, $77 \pm 5 ; p<0.05$; Fig. 2).
We examined the ductus obtained from 19-d gestation mice fetuses to determine whether chronic in utero COX inhibition altered the developmental expression of genes known to affect ductus contractility. Chronic treatment with SC560 plus SC236 altered the expression of genes that regulate $\mathrm{CaL}$ and $\mathrm{K}^{+}$channels (CaL $\alpha 1 \mathrm{c}, \mathrm{CaL} \beta 2, \mathrm{CaL} \beta 3$, Kir6.1, and $\left.\mathrm{Kv} 1.5\right)$, actin or myosin interactions (caldesmon, myocardin, and tropomyosin), matrix production (tenascin $\mathrm{C}$ and $\mathrm{TGF} \beta$ ), and vasodilator activity (hemeoxygenase-1, PDE 1A, PDE 3A, and VEGF; Table 1).

As chronic COX inhibition decreased the expression of genes that facilitate ductus closure late in gestation, we hypothesized that prolonged PGE2 exposure (early in gestation) may have the opposite effect and promote their developmental expression. To test this hypothesis, we used isolated ductus from immature fetal sheep, mounted in organ culture baths. The isolated ductus were incubated in media containing indomethacin to inhibit the increase in tissue prostaglandin production that follows ductus dissection and manipulation (28). Parallel rings from the same ductus were incubated either with or without PGE2 $\left(10^{-8} \mathrm{M}\right)$ for $20 \mathrm{~h}$. In vitro PGE2 exposure increased the expression of genes that regulate $\mathrm{CaL}$ channels ( $\mathrm{CaL} \alpha 1 \mathrm{c}$ and $\mathrm{CaL} \beta 2$ ), $\mathrm{K}+$ channels (Kir6.1 and $\mathrm{Kv} 1.5$ ), and phosphodiesterase activity (PDE 1A and PDE 3A; Table 2). This is consistent with PGE2 having a direct, positive effect on the in utero expression of these genes. On the other hand, PGE2 exposure did not affect the expression of genes that regulate actin or myosin interactions (caldesmon, myocardin, 
Table 1. Real-time PCR measurements of genes involved with ductus closure and remodeling: ductus obtained from 19-d gestation fetuses

\begin{tabular}{|c|c|c|c|c|c|}
\hline \multicolumn{6}{|c|}{$\delta \mathrm{CT}$ (MDH-gene) } \\
\hline \multirow[b]{2}{*}{ Gene } & \multicolumn{2}{|c|}{ Control } & \multicolumn{2}{|c|}{ COX inhibition } & \multirow[b]{2}{*}{$p$} \\
\hline & Mean & SD & Mean & SD & \\
\hline \multicolumn{6}{|l|}{$\mathrm{Ca}^{++}$L-channels } \\
\hline $\mathrm{CaL} \alpha 1 \mathrm{c}$ & -2.33 & \pm 0.52 & -3.09 & \pm 0.31 & $*$ \\
\hline $\mathrm{CaL} \beta 2$ & -2.52 & \pm 0.34 & -3.26 & \pm 0.53 & $*$ \\
\hline $\mathrm{CaL} \beta 3$ & -2.71 & \pm 0.41 & -3.48 & \pm 0.52 & * \\
\hline \multicolumn{6}{|l|}{$\mathrm{K}^{+}$channels } \\
\hline $\mathrm{BKCa}$ & -9.34 & \pm 0.93 & -7.99 & \pm 1.31 & \\
\hline $\mathrm{BKCa} \beta 1$ & -3.70 & \pm 0.52 & -4.30 & \pm 0.36 & $*$ \\
\hline Kir6.1 & -2.44 & \pm 0.72 & -3.52 & \pm 0.87 & * \\
\hline SUR2 & -3.21 & \pm 0.43 & -3.63 & \pm 0.61 & \\
\hline $\mathrm{Kv} 1.2$ & -4.68 & \pm 0.53 & -4.99 & \pm 0.76 & \\
\hline Kv1.5 & -3.11 & \pm 0.36 & -3.99 & \pm 0.48 & $*$ \\
\hline Kv2.1 & -3.53 & \pm 0.83 & -3.69 & \pm 0.71 & \\
\hline Kv9.3 & -1.47 & \pm 0.41 & -2.18 & \pm 0.53 & \\
\hline $\mathrm{Kv} \beta 1.2$ & -3.96 & \pm 0.63 & -4.36 & \pm 0.36 & \\
\hline $\operatorname{Kv} \beta 1.3$ & -1.96 & \pm 0.36 & -2.29 & \pm 0.27 & \\
\hline \multicolumn{6}{|l|}{ Contractility } \\
\hline Caldesmon & -0.03 & \pm 0.21 & -0.76 & \pm 0.41 & $*$ \\
\hline Calponin & -1.58 & \pm 0.55 & -2.01 & \pm 0.49 & \\
\hline Myocardin & -3.17 & \pm 0.38 & -3.97 & \pm 0.31 & $*$ \\
\hline MYH1 & 0.41 & \pm 0.68 & 0.05 & \pm 0.81 & \\
\hline MYH2 & -1.97 & \pm 0.93 & -2.34 & \pm 0.48 & \\
\hline RhoA & -0.94 & \pm 0.74 & -0.80 & \pm 0.44 & \\
\hline RhoB & -2.36 & \pm 0.27 & -2.87 & \pm 0.51 & \\
\hline ROCK1 & -4.02 & \pm 0.81 & -4.27 & \pm 0.64 & \\
\hline NCX1 & -4.29 & \pm 0.95 & -4.92 & \pm 0.60 & \\
\hline PHLBN & -2.88 & \pm 0.68 & -2.98 & \pm 0.51 & \\
\hline SERCA3 & -6.58 & \pm 0.42 & -6.64 & \pm 0.23 & \\
\hline Tropomyosin & -3.00 & \pm 0.39 & -3.80 & \pm 0.54 & $*$ \\
\hline \multicolumn{6}{|l|}{ Endothelin } \\
\hline ECE1 & -1.18 & \pm 0.68 & -1.86 & \pm 0.26 & \\
\hline ET1 & -4.43 & \pm 0.95 & -4.55 & \pm 0.62 & \\
\hline ETAr & -5.99 & \pm 1.52 & -6.27 & \pm 1.67 & \\
\hline $\mathrm{ETBr}$ & -2.66 & \pm 0.79 & -2.77 & \pm 0.37 & \\
\hline \multicolumn{6}{|l|}{ Vasodilation } \\
\hline COX1 & -5.34 & \pm 0.37 & -5.29 & \pm 0.69 & \\
\hline $\mathrm{COX} 2$ & -5.53 & \pm 0.58 & -4.75 & \pm 0.89 & \\
\hline eNOS & -8.86 & \pm 0.91 & -9.68 & \pm 1.43 & \\
\hline $\mathrm{EP} 2$ & -8.16 & \pm 1.00 & -7.76 & \pm 0.36 & \\
\hline EP3 & -5.46 & \pm 0.27 & -5.63 & \pm 0.62 & \\
\hline EP4 & -0.20 & \pm 1.20 & -0.71 & \pm 0.87 & \\
\hline HO1 & -3.52 & \pm 0.31 & -1.48 & \pm 0.97 & $*$ \\
\hline $\mathrm{HO} 2$ & -2.51 & \pm 0.42 & -2.51 & \pm 0.28 & \\
\hline PDE1A & -5.22 & \pm 0.40 & -5.89 & \pm 0.19 & $*$ \\
\hline PDE1B & -2.52 & \pm 1.03 & -2.83 & \pm 0.48 & \\
\hline PDE3A & -2.38 & \pm 0.28 & -3.41 & \pm 0.54 & $*$ \\
\hline PDE3B & -2.80 & \pm 0.52 & -3.05 & \pm 0.13 & \\
\hline PDE4D & -6.22 & \pm 0.69 & -6.51 & \pm 0.30 & \\
\hline PDE5A & -2.75 & \pm 0.36 & -3.26 & \pm 0.55 & \\
\hline \multicolumn{6}{|l|}{ Remodeling } \\
\hline Ang-1 & -4.44 & \pm 0.54 & -4.76 & \pm 0.36 & \\
\hline Ang-2 & -5.91 & \pm 0.47 & -5.82 & \pm 0.74 & \\
\hline ATIIR-1 & -4.96 & \pm 0.72 & -5.08 & \pm 0.45 & \\
\hline HAS2 & -4.69 & \pm 0.45 & -4.99 & \pm 0.19 & \\
\hline HIF1 $\alpha$ & -3.75 & \pm 0.87 & -3.99 & \pm 0.25 & \\
\hline $\operatorname{HIF} 2 \alpha$ & -2.71 & \pm 0.66 & -2.76 & \pm 0.44 & \\
\hline $\mathrm{IFN} \gamma$ & -3.07 & \pm 0.54 & -3.18 & \pm 0.25 & \\
\hline IL6 & -3.66 & \pm 0.37 & -4.06 & \pm 0.26 & \\
\hline PDGF-B & -5.06 & \pm 0.45 & -5.19 & \pm 0.54 & \\
\hline Tenascin-C & -1.60 & \pm 0.30 & -2.13 & \pm 0.36 & * \\
\hline TFAP $2 b$ & -4.81 & \pm 1.34 & -5.36 & \pm 1.05 & \\
\hline TGF $\beta 1$ & -4.17 & \pm 0.37 & -4.67 & $\begin{array}{r} \pm 0.29 \\
\quad(\text { Con }\end{array}$ & $\begin{array}{r}* \\
\text { ed) }\end{array}$ \\
\hline
\end{tabular}

Table 1. Continued

\begin{tabular}{llllllll}
\hline \multicolumn{3}{c}{$\delta$ CT (MDH-gene) } & & \\
\hline & \multicolumn{3}{c}{ Control } & & \multicolumn{2}{c}{$\begin{array}{c}\text { COX } \\
\text { inhibition }\end{array}$} \\
\cline { 2 - 3 } Gene & Mean & SD & & Mean & SD & $p$ \\
\hline TGF $\beta 3$ & -2.71 & \pm 0.23 & & -3.43 & \pm 0.21 & $*$ \\
TNF $\alpha$ & -2.38 & \pm 1.00 & & -2.69 & \pm 0.29 & \\
TRAF1 & -5.96 & \pm 1.05 & & -6.31 & \pm 0.53 & \\
VEGF & -3.57 & \pm 0.50 & & -2.78 & \pm 0.42 & $*$ \\
\hline
\end{tabular}

$\delta \mathrm{CT}$ (MDH-gene), difference in cycle threshold between the expression of the housekeeping gene Malate dehydrogenase (MDH) and the gene of interest. Each unit of $\delta \mathrm{CT}$ (MDH-gene) represents a 2-fold increase in a gene's mRNA. The more negative the $\delta \mathrm{CT}(\mathrm{MDH}-\mathrm{gene})$, the fewer the number of starting copies of a gene (mRNA). Number of separate litters used: control (d 19), 9; COX-inhibition (d 15-19), 7. From each litter of mice, we obtained and pooled between 10 and 12 ductus.

$* p<0.05$.

MYH, myosin heavy chain; ROCK1, Rho kinase 1 ; NCX1, $\mathrm{Na}^{+} / \mathrm{Ca}^{++}$ exchanger; PHLBN, phospholamban; SERCA, sarcoplasmic reticulum $\mathrm{Ca}^{++}-$ ATPase; ECE, endothelin converting enzyme; ET, endothelin; ETAr, endothelin receptor A; eNOS, endothelial nitric oxide synthase; EP, prostaglandin E receptor; $\mathrm{HO}$, heme oxygenase; $\mathrm{PDE}$, phosphodiesterase; ang, angiopoietin; ATIIR-1, angiotensin II receptor; HAS, hyaluronic acid synthase; HIF, hypoxia inducible factor.

and tropomyosin) or matrix production (tenascin $\mathrm{C}$ and $\mathrm{TGF} \beta$ ). We also examined the expression of several genes that were not affected by chronic COX inhibition in utero (large conductance $\mathrm{BKCa}$ channel, endothelin-1, platelet derived growth factor-B chain, Rho A, Rho B, and ROCK-1). As might be anticipated, PGE2 exposure did not affect their expression.

\section{DISCUSSION}

Although acute COX inhibition in near-term mice led to fetal ductus constriction (Fig. 1), prolonged COX inhibition during the last $25 \%$ of gestation led to an impaired contractile response and an incomplete closure in the newborn (Fig. 1). The effects of prolonged COX inhibition in utero are similar to the effects observed after deletion of both COX genes in utero (6-8). Similar findings have also been observed in larger species [e.g. humans (2) and sheep (5)] after indomethacin exposure in utero. In larger species, however, the loss of ductus contractility, after $\mathrm{COX}$ inhibition, seems to be due to ischemia of the ductus wall secondary to in utero ductus constriction and loss of vasa vasorum blood flow to the muscle media (5). Ductus wall ischemia does not seem to be the explanation for our findings in mice. The mouse ductus is so thin that luminal flow sustains all of its nutrient needs. As a result, the mouse ductus has no need for muscle media vasa vasorum $(34,35)$. In our study, COX inhibition was started on d 15, when COX inhibitors do not contract the mouse ductus (6). Chronic COX inhibition (between d 15 and 19) does not affect the in utero dimensions of the ductus lumen (6) (Fig. 1). Consistent with these findings, surrogate markers of hypoxia, like HIF1 $\alpha$ and HIF2 $\alpha$, whose expression increases during ductus hypoxia (36), are unaffected by chronic COX inhibition in utero (Table 1). 
Table 2. Real-time PCR measurements in sheep ductus

\begin{tabular}{|c|c|c|c|c|c|}
\hline \multicolumn{6}{|c|}{$\delta \mathrm{CT}(\mathrm{MDH}$-gene) } \\
\hline \multirow[b]{2}{*}{ Gene } & \multicolumn{2}{|c|}{ Control } & \multicolumn{2}{|c|}{ PGE2 incubation } & \multirow[b]{2}{*}{$p$} \\
\hline & Mean & SD & Mean & SD & \\
\hline \multicolumn{6}{|c|}{ Genes affected by chronic COX inhibition in utero } \\
\hline $\mathrm{CaL} \alpha 1 \mathrm{c}$ & -0.24 & \pm 0.49 & 0.59 & \pm 0.54 & $*$ \\
\hline $\mathrm{CaL} \beta 2$ & -2.31 & \pm 1.01 & -1.33 & \pm 0.83 & $*$ \\
\hline $\mathrm{CaL} \beta 3$ & -1.28 & \pm 0.38 & -1.12 & \pm 0.31 & \\
\hline Caldesmon & 1.12 & \pm 0.78 & 1.11 & \pm 0.63 & \\
\hline $\mathrm{BKCa} \beta 1$ & -4.40 & \pm 0.26 & -4.06 & \pm 0.44 & \\
\hline $\mathrm{HO} 1$ & -2.08 & \pm 0.38 & -1.59 & \pm 0.47 & $*$ \\
\hline Kir6.1 & -5.21 & \pm 1.00 & -4.31 & \pm 0.92 & $*$ \\
\hline Kv1.5 & -1.99 & \pm 1.40 & -0.96 & \pm 0.87 & $*$ \\
\hline Myocardin & -3.40 & \pm 0.47 & -3.29 & \pm 0.77 & \\
\hline PDE1A & -5.79 & \pm 1.02 & -4.72 & \pm 0.95 & $*$ \\
\hline PDE3A & -2.58 & \pm 0.66 & -1.62 & \pm 0.96 & $*$ \\
\hline Tenascin-C & 1.00 & \pm 0.81 & 0.64 & \pm 1.18 & \\
\hline TGF $\beta 1$ & -0.61 & \pm 0.34 & -0.35 & \pm 0.31 & \\
\hline TGF $\beta 3$ & -4.09 & \pm 0.76 & -3.76 & \pm 0.64 & \\
\hline Tropomyosin & -0.25 & \pm 1.01 & -0.50 & \pm 0.58 & \\
\hline VEGF & 0.31 & \pm 0.72 & 1.61 & \pm 0.86 & $*$ \\
\hline \multicolumn{6}{|c|}{ Genes un-affected by chronic COX inhibition in utero } \\
\hline $\mathrm{BKCa}$ & -7.13 & \pm 0.98 & -7.27 & \pm 0.55 & \\
\hline $\mathrm{COX} 2$ & 0.77 & \pm 0.96 & 1.06 & \pm 1.36 & \\
\hline $\mathrm{EP} 2$ & -1.86 & \pm 0.43 & -1.96 & \pm 0.85 & \\
\hline $\mathrm{EP} 3$ & -5.44 & \pm 1.03 & -4.99 & \pm 0.98 & \\
\hline ET1 & -4.52 & \pm 1.33 & -4.74 & \pm 1.22 & \\
\hline PDGF-B & -3.95 & \pm 0.83 & -3.91 & \pm 0.71 & \\
\hline RhoA & 1.87 & \pm 0.41 & 2.07 & \pm 0.39 & \\
\hline RhoB & 2.42 & \pm 0.61 & 2.80 & \pm 0.78 & \\
\hline ROCK1 & -2.82 & \pm 0.75 & -2.49 & \pm 0.59 & \\
\hline SUR2 & -1.04 & \pm 0.41 & -0.78 & \pm 0.55 & \\
\hline
\end{tabular}

Rings from the same sheep ductus were incubated with or without PGE2 $\left(10^{-8} \mathrm{M}\right)$ for $20 \mathrm{~h}$. We examined the expression of genes that were altered by chronic COX inhibition in utero in Table 1. We also examined the expression of several of the genes that were not affected by chronic COX inhibition (see Table 1). Number of separate animals used, 7.

$* p<0.05$.

We hypothesized that PGE2 may play a unique role in the development of ductus contractility that is distinct from its function as a vasodilator. Previous studies found that gene deletion of the PGE2 receptor EP4 produced a persistent PDA phenotype in newborn mice (37) that was similar to what occurs after COX gene deletion or chronic in utero COX inhibition. Our findings are consistent with PGE2 having a direct effect on ductus contractility by increasing the developmental expression of genes that regulate calcium availability. The developmentally regulated, oxygen-induced constriction of the ductus seems to be due in large part to the increased expression of $\mathrm{CaL}$ channels $(11,15)$ and oxygen-sensitive $\mathrm{K}^{+}$ channels $(11,14,15)$. In our experiments, in vitro exposure to PGE2 increased the expression of CaL channel (CaL $\alpha 1 \mathrm{c}$ and $\mathrm{CaL} \beta 2$ ) and $\mathrm{K}^{+}$channel (Kir6.1 and Kv1.5) genes without affecting genes that regulate Rho-kinase-mediated calcium sensitization (Table 2). Conversely, inhibition of prostaglandin production, by chronic in utero $\mathrm{COX}$ inhibition, decreased the expression of the same $\mathrm{CaL}$ and $\mathrm{K}^{+}$channel genes, without affecting Rho-kinase-associated genes (Table 1).

The effects of chronic in utero COX inhibition on gene expression are consistent with the effects we found on ductus contractility. Contractile stimuli, which act primarily on ductus $\mathrm{K}^{+}$and CaL channels [like $\mathrm{O}_{2}$ and $\mathrm{K}^{+}(11-14,17,32)$ ], have a diminished contractile effect, whereas U46619, which has been shown to affect both calcium entry and Rho-kinasemediated calcium sensitization in other vascular tissues $(32,33)$, constricts control and COX-inhibited ductus to a similar degree (Fig. 2).

Several other genes were also affected by chronic COX inhibition and may contribute to the delayed ductus closure after birth (Table 1). Previous studies have shown that a developmental increase in phosphodiesterase (PDE 1A and PDE 3A) expression and activity decreases the sensitivity of the late gestation ductus to vasodilators, like PGE2 (38). We found that the phosphodiesterase genes were downregulated by chronic COX inhibition in utero (Table 1) and upregulated by PGE2 exposure in vitro (Table 2). This is consistent with endogenous PGE2 having a direct, positive effect on PDE 1A and PDE 3A expression in utero.

Conversely, the effects of chronic COX inhibition on other genes (like caldesmon, myocardin, tropomyosin, tenascin $\mathrm{C}$, $\operatorname{TGF} \beta$, hemeoxygenase-1, and VEGF) may not be due to the direct effects of PGE2 on the ductus. For example, genes that regulate actin or myosin interactions (caldesmon, myocardin, and tropomyosin) and matrix production (tenascin $\mathrm{C}$ and $\mathrm{TGF} \beta$; which were decreased by chronic COX inhibition in utero) were not affected by incubation with PGE2 in vitro; and the hemeoxygenase- 1 and VEGF genes, which were increased by chronic COX inhibition in utero, were not decreased by 
incubation with PGE2 in vitro. The effects of chronic COX inhibition on these genes may be due to the distal effects of COX inhibition on other maternal, placental, or fetal organs. The fact that PGE2 incubation did not produce the opposite effect as chronic COX inhibition for this set of genes may also be due to differences in the experimental design (in vitro versus in vivo) or the species used (sheep versus mice).

Increased NO production has been implicated in delayed ductus closure after prolonged COX inhibition in utero (9). Functional coupling of COX and NOS systems is a wellrecognized phenomenon $(5,9)$. In the mouse ductus arteriosus, eNOS is the predominant isoform for NO production (35). We did not observe a change in ductus eNOS expression after chronic COX inhibition; however, we did observe changes in PDE1A and VEGF expression, which could contribute to increased NO activity or production (Table 1). Our contractility experiments were not designed to examine the effects of chronic COX inhibition on the production of NO or other vasodilators. We were primarily interested in examining the effects of COX inhibition on the contractile apparatus. Therefore, we specifically incubated the isolated ductus with inhibitors of prostaglandin and NO production to eliminate any differences between the groups in in vitro prostaglandin and NO production.

Our studies examine the chronic effects of COX inhibition and PGE2 stimulation on ductus gene expression and contractility. They do not identify the mechanism(s) by which PGE2 is able to affect these changes. Previously, cAMP has been shown to regulate $\mathrm{K}^{+}$channel activity and expression in excitable cells (39); a similar mechanism may mediate the effects of PGE2 on $\mathrm{CaL}$ and $\mathrm{K}^{+}$channel gene expression in these experiments. Future studies, designed to measure protein expression and intracellular ion fluxes, will be necessary to identify the exact pathways that have been altered by our pharmacologic manipulations.

In summary, we speculate that the paradoxical effects of acute and chronic COX inhibition are consistent with the existence of two complementary roles for PGE2 during ductus development: one that promotes the expression of pathways necessary for its oxygen-induced closure after delivery, and second that maintains ductus patency for fetal wellbeing. A better understanding of these two processes will be important for the development of new strategies to treat preterm labor without affecting fetal vascular development.

\section{REFERENCES}

1. Huhta JC, Moise KJ, Fisher DJ, Sharif DS, Wasserstrum N, Martin C 1987 Detection and quantitation of constriction of the fetal ductus arteriosus by Doppler echocardiography. Circulation 75:406-412

2. Norton ME, Merrill J, Cooper BA, Kuller JA, Clyman RI 1993 Neonatal complications after the administration of indomethacin for preterm labor. N Engl J Med 329:1602-1607

3. Hammerman C, Glaser J, Kaplan M, Schimmel MS, Ferber B, Eidelman AI 1998 Indomethacin tocolysis increases postnatal patent ductus arteriosus. Pediatrics 102:E56

4. Clyman RI, Chorne N 2007 Patent ductus arteriosus: evidence for and against treatment. J Pediatr 150:216-219

5. Clyman RI, Chen YQ, Chemtob S, Mauray F, Kohl T, Varma DR, Roman C 2001 In utero remodeling of the fetal lamb ductus arteriosus: the role of antenatal indomethacin and avascular zone thickness on vasa vasorum proliferation, neointima formation, and cell death. Circulation 103:1806-1812

6. Reese J, Anderson JD, Brown N, Roman C, Clyman RI 2006 Inhibition of cyclooxygenase isoforms in late- but not midgestation decreases contractility of the ductus arteriosus and prevents postnatal closure in mice. Am J Physiol Regul Integr Comp Physiol 291:R1717-R1723

7. Loftin CD, Trivedi DB, Tiano HF, Clark JA, Lee CA, Epstein JA, Morham SG, Breyer MD, Nguyen M, Hawkins BM, Goulet JL, Smithies O, Koller BH, Langenbach R 2001 Failure of ductus arteriosus closure and remodeling in neonatal mice deficient in cyclooxygenase-1 and cyclooxygenase-2. Proc Natl Acad Sci USA 98:1059-1064

8. Reese J, Paria BC, Brown N, Zhao X, Morrow JD, Dey SK 2000 Coordinated regulation of fetal and maternal prostaglandins directs successful birth and postnatal adaptation in the mouse. Proc Natl Acad Sci USA 97:9759-9764

9. Baragatti B, Brizzi F, Ackerley C, Barogi S, Ballou LR, Coceani F 2003 Cyclooxygenase-1 and cyclooxygenase- 2 in the mouse ductus arteriosus: individual activity and functional coupling with nitric oxide synthase. Br J Pharmacol 139:1505-1515

10. Yokoyama U, Minamisawa S, Quan H, Ghatak S, Akaike T, Segi-Nishida E, Iwasaki S, Iwamoto M, Misra S, Tamura K, Hori H, Yokota S, Toole BP, Sugimoto Y, Ishikawa Y 2006 Chronic activation of the prostaglandin receptor EP4 promotes hyaluronan-mediated neointimal formation in the ductus arteriosus. J Clin Invest 116:3026-3034

11. Clyman RI, Waleh NS, Kajino H, Roman C, Mauray F 2007 Calcium-dependent and calcium-sensitizing pathways in the mature and immature ductus arteriosus. Am J Physiol Regul Integr Comp Physiol 293:R1650-R1656

12. Nakanishi T, Gu H, Hagiwara N, Momma K 1993 Mechanisms of oxygen-induced contraction of ductus arteriosus isolated from the fetal rabbit. Circ Res 72:12181228

13. Tristani-Firouzi M, Reeve HL, Tolarova S, Weir EK, Archer SL 1996 Oxygeninduced constriction of rabbit ductus arteriosus occurs via inhibition of a 4-aminopyridine-, voltage-sensitive potassium channel. J Clin Invest 98:1959-1965

14. Thebaud B, Michelakis ED, Wu XC, Moudgil R, Kuzyk M, Dyck JR, Harry G, Hashimoto K, Haromy A, Rebeyka I, Archer SL 2004 Oxygen-sensitive Kv channel gene transfer confers oxygen responsiveness to preterm rabbit and remodeled human ductus arteriosus: implications for infants with patent ductus arteriosus. Circulation 110:1372-1379

15. Thebaud B, Wu XC, Kajimoto H, Bonnet S, Hashimoto K, Michelakis ED, Archer SL 2008 Developmental absence of the $\mathrm{O} 2$ sensitivity of L-type calcium channels in preterm ductus arteriosus smooth muscle cells impairs $\mathrm{O} 2$ constriction contributing to patent ductus arteriosus. Pediatr Res 63:176-181

16. Kajimoto H, Hashimoto K, Bonnet SN, Haromy A, Harry G, Moudgil R, Nakanishi T, Rebeyka I, Thebaud B, Michelakis ED, Archer SL 2007 Oxygen activates the Rho/Rho-kinase pathway and induces RhoB and ROCK-1 expression in human and rabbit ductus arteriosus by increasing mitochondria-derived reactive oxygen species. A newly recognized mechanism for sustaining ductal constriction. Circulation 115:1777-1788

17. Hong Z, Hong F, Olschewski A, Cabrera JA, Varghese A, Nelson DP, Weir EK 2006 Role of store-operated calcium channels and calcium sensitization in normoxic contraction of the ductus arteriosus. Circulation 114:1372-1379

18. Costa M, Barogi S, Socci ND, Angeloni D, Maffei M, Baragatti B, Chiellini C, Grasso E, Coceani F 2006 Gene expression in ductus arteriosus and aorta: comparison of birth and oxygen effects. Physiol Genomics 25:250-262

19. Kim HS, Aikawa M, Kimura K, Kuro-o M, Nakahara K, Suzuki T, Katoh H, Okamoto E, Yazaki Y, Nagai R 1993 Ductus arteriosus. Advanced differentiation of smooth muscle cells demonstrated by myosin heavy chain isoform expression in rabbits. Circulation 88:1804-1810

20. Slomp J, Gittenberger-de Groot AC, Glukhova MA, Conny van Munsteren J, Kockx MM, Schwartz SM, Koteliansky VE 1997 Differentiation, dedifferentiation, and apoptosis of smooth muscle cells during the development of the human ductus arteriosus. Arterioscler Thromb Vasc Biol 17:1003-1009

21. Morano I, Chai GX, Baltas LG, Lamounier-Zepter V, Lutsch G, Kott M, Haase H, Bader M 2000 Smooth-muscle contraction without smooth-muscle myosin. Nat Cell Biol 2:371-375

22. Huang J, Cheng L, Li J, Chen M, Zhou D, Lu MM, Proweller A, Epstein JA, Parmacek MS 2008 Myocardin regulates expression of contractile genes in smooth muscle cells and is required for closure of the ductus arteriosus in mice. J Clin Invest 118:515-525

23. Takizawa T, Oda T, Arishima K, Yamamoto M, Masaoka T, Somiya H, Akahori F, Shiota K 1994 A calcium channel blocker verapamil inhibits the spontaneous closure of the ductus arteriosus in newborn rats. J Toxicol Sci 19:171-174

24. Loftin CD, Trivedi DB, Langenbach R 2002 Cyclooxygenase-1-selective inhibition prolongs gestation in mice without adverse effects on the ductus arteriosus. J Clin Invest 110:549-557

25. Bouayad A, Kajino H, Waleh N, Fouron JC, Andelfinger G, Varma DR, Skoll A, Vazquez A, Gobeil F Jr, Clyman RI, Chemtob S 2001 Characterization of PGE2 receptors in fetal and newborn lamb ductus arteriosus. Am J Physiol Heart Circ Physiol 280:H2342-H2349

26. Reese J, O'Mara PW, Poole SD, Brown N, Tolentino C, Eckman DM, Aschner JL 2008 Regulation of the fetal mouse ductus arteriosus is dependent on interaction of nitric oxide and COX enzymes in the ductal wall. Prostaglandins Other Lipid Mediat, in press

27. Sodini D, Baragatti B, Barogi S, Laubach VE, Coceani F 2008 Indomethacin promotes nitric oxide function in the ductus arteriosus in the mouse. Br J Pharmacol 153:1631-1640

28. Kajino H, Chen YQ, Seidner SR, Waleh N, Mauray F, Roman C, Chemtob S, Koch CJ, Clyman RI 2001 Factors that increase the contractile tone of the ductus arteriosus also regulate its anatomic remodeling. Am J Physiol Regul Integr Comp Physiol 281:R291-R301

29. Challis JR, Dilley SR, Robinson JS, Thorburn GD 1976 Prostaglandins in the circulation of the fetal lamb. Prostaglandins 11:1041-1052 
30. Urban NH, Berg KM, Ratz PH $2003 \mathrm{~K}+$ depolarization induces RhoA kinase translocation to caveolae and $\mathrm{Ca} 2+$ sensitization of arterial muscle. Am J Physiol Cell Physiol 285:C1377-C1385

31. Janssen LJ, Tazzeo T, Zuo J, Pertens E, Keshavjee S $2004 \mathrm{KCl}$ evokes contraction of airway smooth muscle via activation of RhoA and Rho-kinase. Am J Physiol Lung Cell Mol Physiol 287:L852-L858

32. Nobe K, Paul RJ 2001 Distinct pathways of $\mathrm{Ca}(2+)$ sensitization in porcine coronary artery: effects of Rho-related kinase and protein kinase $\mathrm{C}$ inhibition on force and intracellular $\mathrm{Ca}(2+)$. Circ Res 88:1283-1290

33. Cogolludo A, Moreno L, Lodi F, Tamargo J, Perez-Vizcaino F 2005 Postnatal maturational shift from PKCzeta and voltage-gated $\mathrm{K}+$ channels to RhoA/Rho kinase in pulmonary vasoconstriction. Cardiovasc Res 66:84-93

34. Tada T, Kishimoto H 1990 Ultrastructural and histological studies on closure of the mouse ductus arteriosus. Acta Anat (Basel) 139:326-334

35. Richard C, Gao J, LaFleur B, Christman BW, Anderson J, Brown N, Reese J 2004 Patency of the preterm fetal ductus arteriosus is regulated by endothelial nitric oxide synthase and is independent of vasa vasorum in the mouse. Am J Physiol Regul Integr Comp Physiol 287:R652-R660

36. Levin M, McCurnin D, Seidner SR, Yoder B, Waleh N, Goldbarg S, Roman C, Liu BM, Boren J, Clyman RI 2006 Postnatal constriction, ATP depletion, and cell death in the mature and immature ductus arteriosus. Am J Physiol Regul Integr Comp Physiol 290:R359-R364

37. Nguyen M, Camenisch T, Snouwaert JN, Hicks E, Coffman TM, Anderson PA, Malouf NN, Koller BH 1997 The prostaglandin receptor EP4 triggers remodelling of the cardiovascular system at birth. Nature 390:78-81

38. Liu H, Manganiello VC, Clyman RI 2008 Expression, activity and function of cAMP and cGMP phosphodiesterases in the mature and immature ductus arteriosus. Pediatr Res 64:477-481

39. Mori Y, Matsubara H, Folco E, Siegel A, Koren G 1993 The transcription of a mammalian voltage-gated potassium channel is regulated by cAMP in a cell-specific manner. J Biol Chem 268:26482-26493 